\title{
PENANGANAN LIMBAH PLASTIK \\ PADA HUTAN BAKAU DI KAWASAN DAM ESTUARI DENPASAR SELATAN
}

Sidhi Bayu Turker, Ni Kadek Widyastuti, Putu Steven Eka Putra, Ni Luh Christine Prawitha Sari Suyasa, I Nengah Rata Artana

Email: sidhiturker@undhirabali.ac.id,widya.astuty1979@gmail.com, putustevenekaputra@gmail.com,Christine.suyasa@undhirabali.ac.id, nengahrata699@gmail.com

\begin{abstract}
ABSTRAK
Kelompok Nelayan Segara Guna Batu Lumbang merupakan kelompok nelayan yang secara tradisional mengelola satu area Kawasan Konservasi Wisata Taman Hutan Raya Bakau Ngurah Rai Denpasar. Prodi D4 Manajemen Perhotelan Universitas Dhyana Pura bekerjasama dengan kelompok nelayan tersebut sejak 2017 sampai sekarang dalam berbagai kegiatan konservasi. Kawasan tersebut memiliki permasalahan terkait sampah kiriman dari beberapa sungai yakni Tukad Badung, Tukad Mati dan Dam Estuari Denpasar. Kondisi ini menyebabkan berkurangnya keasrian kawasan itu sebagai obyek dan atraksi wisata. Limbah kiriman yang cukup berbahaya adalah sampah plastik yang dapat mengganggu pertumbuhan bibit bakau dan kesehatan perairan di tempat itu. Untuk membantu mengatasi dampak tersebut dilakukanlah kegiatan pengabdian kepada masyarakat berupa pembersihan kawasan hutan bakau bersama kelompok nelayan menggunakan metode ceramah, diskusi, dan tindakan langsung pengambilan plastik menggunakan pengait manual memakai transportasi kano. Kegiatan itu berhasil mengumpulkan $200 \mathrm{~kg}$ sampah plastik, dan sebuah model pendekatan pembelajaran edukasi yang yang memadukan program edukasi konservasi lingkungan dan praktek langsung. Kegiatan PKM ini berdampak positif dalam mendukung kawasan perairan hutan bakau sebagai obyek dan atraksi wisata perairan berdasarkan prinsip-prinsip sustainable tourism development
\end{abstract}

Keywords: sustainable tourism development, taman hutan raya bakau, limbah plastik, edukasi wisata lingkungan, obyek dan atraksi wisata 


\section{PENDAHULUAN}

Bali sebagai salah satu destinasi pariwisata dunia merupakan salah satu daerah tujuan pariwisata yang sangat diperhitungkan terutama di kawasan Asia dan Pacifik. Pertumbuhan jumlah kunjungan pariwisata dalam lima tahun terakhir menunjukkan terjadinya peningkatan jumlah kunjungan. Pembangunan sarana dan prasarana beserta fasilitas yang terus dilakukan antara lain pembenahan pengembangan pelabuhan udara dimaksudkan untuk mampu mengantisipasi pertumbuhan jumlah kunjungan wisatawan yang terus meningkat. Kesiapan destinasi dengan segala bentuk infra dan supra strukturnya, atraksi yang disiapkan, dan kemudahan yang disiapkan oleh pemerintah dan seluruh komponen stake-holder pariwisata Bali adalah untuk menjaring jumlah kunjungan wisatawan semakin meningkat.

Di beberapa kawasan pantai di Bali banyak ditumbuhi pohon bakau yang sering disebut sebagai Hutan Bakau. Salah satu kawasan yang mudah ditemui berada disepanjang jalan Bypass Ngurah Rai dari Denpasar menuju Bandara Ngurah Rai. Kawasan tersebut di kenal sebagai Kawasan Konservasi Wisata Taman Hutan Raya Ngurah Rai yang terletak di Desa Suwung Kauh Kotamadya Denpasar.

Kerjasama UPT Tahura Ngurah Rai dengan berbagai kelompok nelayan telah terbina dengan baik. Kelompok-kelompok nelayan ini menjaga dengan baik pertumbuhan dan kebersihan lingkungannya, serta adanya dukungan penuh dari masyarakat setempat yang sudah menyadari pentingnya melestarikan hutan bakau dan salah satu kawasan tersebut adalah Kelompok Nelayan Segara Guna Batu Lumbang Denpasar. Sebagai kawasan yang sedang dikembangkan kawasan ini mendapat kunjungan wisatawan baik lokal, nasional maupun internasional.

Kerjasama yang dibangun dalam bentuk partisipasi bersama masyarakat dalam kegiatan pengabdian tersebut didasarkan pada tujuan memberikan manfaat positif bagi masyarakat penerima melalui berbagai bentuk kegiatan yang didasarkan pada kebutuhan nyata masyarakat dalam bentuk berbagai pendampingan sehingga sebuah bentuk kegiatan itu dirasakan manfaatnya oleh masyarakat (Wearing, 2001). Manfaat yang diperoleh masyarakat penerima harus didasarkan pada cakupan dan skala yang luas berkelanjutan (Holmes, et.all, 2009). Hawkins (2005) menyebutkan hasil kegiatan supaya memberikan kontribusi dalam berbagai hal bagi masyarakat di destinasi pelaksanaan kegiatan sebagai upaya untuk memperbaiki citra dan kualitas penampilan kawasan di tempat tersebut. Lamoureux (2015) menekankan bahwa kegiatan di sebuah destinasi tidak hanya bermanfaat bagi kelompok masyarakat tertentu tapi juga bagi pemangku kepentingan karena menguntungkan masyarakat penerima, secara finansial memberikan manfaat yang jelas, dilakukan oleh organisasi penyelenggara yang memiliki kredibilitas serta diterima oleh masyarakat, dan menjamin kelanjutan jangka panjang industri pariwisata.

Langkah-langkah yang dilakukan dalam mewujudkan kegiatan pengabdian perlu dilakukan secara terpadu. Callanan, et all, (2007) menekankan bahwa semua bentuk kegiatan yang akan mendukung perbaikan lingkungan di destinasi wisata supaya melakukan dekontruksi aktifitas kegiatan dengan menyertakan bentuk kegiatan yang mengedepankan social tourism, cultural tourism, eco- tourism, responsible tourism. Sementara Hooloway, et all, (2009) menekankan kegiatan sosial apapun bentuknya terlebih yang dilakukan oleh lembaga pendidikan supaya tertata dengan perencanaan dan tidak bersifat spontanitas. WTO (1993), OECD (2001) dalam WTTC Report Agenda 21 menekankan kegiatan yang bertujuan untuk membantu kelompok masyarakat tertentu dalam meminimalkan persoalan-persoalan yang muncul harus melihat secara menyeluruh pada beberapa masalah seperti lingkungan, sosial budaya, ekonomi, perubahan iklim, keamanan, kesehatan dan lain-lain.

Sebagai kawasan hutan bakau yang mendapat kiriman air dari beberapa sungai yakni Tukad Badung, Tukad Mati dan Dam Estuari Denpasar maka kawasan hutan bakau Denpasar Selatan menerima kiriman limbah 
sampah berbagai jenis termasuk diantaranya yang dominan adalah limbah plastik. Bengen (2002) menyebutkan bahwa dampak limbah merupakan salah satu aspek kebiasaan manusia (terutama masyarakat sekitar hutan bakau) yang menimbulkan persoalan pada lingkungan secara langsung. Kondisi ini menyebabkan berkurangnya keindahan dan keasrian kawasan hutan bakau Denpasar Selatan sebagai obyek dan atraksi wisata yang menjadi wilayah pelayanan Kelompok Nelayan Segara Guna Batu Lumbang Denpasar. Untuk mengatasi dampak tersebut maka dilakukanlah kegiatan pengabdian kepada masyarakat dengan tujuan (1) mendukung kelompok nelayan mengatasi persoalan limbah plastik di kawasan hutan bakau; (2) mendukung perluasan kawasan hutan bakau melalui kegiatan penanaman pohon bakau; (3) memberikan penguatan tentang pembelajaran edukasi lingkungan yang dapat diterapkan oleh lembaga-lembaga pendidikan sebagai sebuah bentuk kegiatan pembangunan pariwisata yang berkelanjutan di kawasan perairan hutan bakau Denpasar Selatan.

\section{METODE}

Metode yang dilakukan dalam memaksimalkan pelaksanaan kegiatan tersebut dilakukan dengan (1) diskusi dengan pengurus kelompok nelayan untuk membahasakan permasalahan yang dihadapi; (2) melakukan observasi lapangan dan merencanakan langkah-langkah kegiatan lapangan mulai dari penyiapan peralatan, waktu pelaksanaan, koordinasi pelaksanaan, proses penanganan penampungan sampah plastik; penyampaian ceramah edukasi oleh ketua kelompok nelayan kepada mahasiswa tentang kegiatan konservasi perairan hutan bakau di lingkungan kerja Kelompok Nelayan Segara Guna Batu Lumbang Denpasar; (4) melakukan kegiatan lapangan secara langsung dengan menggunakan peralatan dan fasilitas yang disiapkan pengrus kelompok nelayan dibawah bimbingan para nelayan yang bertugas sebagai pendamping.

\section{JADWAL PENGABDIAN KEPADA MASYARAKAT (PKM)}

Dari hasil percakapan dan pendekatan awal maka disusunlah jadwal pelaksanaan kegiatan PKM sebagai berikut:

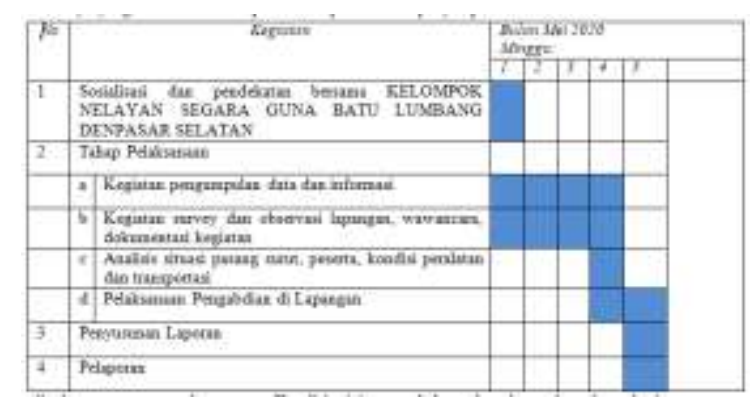

HASIL DAN PEMBAHASAN

\section{Hasil Diskusi dan Ceramah}

Dari hasil diskusi bersama pengurus dan anggota kelompok nelayan dipadukan dengan ceramah edukasi yang disampaikan oleh ketua pengurus kelompok nelayan diperoleh beberapa informasi yang memberikan pemahaman lebih mendalam tentang fungsi kawasan perairan hutan bakau bagi lingkungan dan konservasi perairan.

Kawasan hutan bakau disepanjang jalan Bypass Ngurah Rai dari Denpasar menuju Bandara Ngurah Rai di kenal sebagai Kawasan Konservasi Wisata Taman Hutan Raya Ngurah Rai yang terletak di Desa Suwung Kauh Kotamadya Denpasar di bawah tanggungjawab UPT. Taman Hutan Raya (Tahura) Ngurah Rai yang memiliki peran penting dalam mengelola taman hutan raya secara professional dan berkelanjutan guna menjamin berlangsungnya fungsi-fungsi ekosistem taman hutan raya (hutan bakau) secara optimal dan lestari melalui pemberdayaan masyarakat untuk mendukung pelestarian budaya dan tujuan wisata yang berorientasi pada aspek ekologis, sosial dan pemanfaatan hutan secara lestari. Ekosistem pada kawasan hutan bakau memiliki peranan ekologi, sosial-ekonomi,dan sosial-budaya yang sangat penting; misalnya menjaga stabilitas pantai dari abrasi, sumber ikan, udang dan keanekaragaman hayati lainnya, sumber kayu bakar dan kayu bangunan, serta 
memiliki fungsi konservasi, pendidikan, ekoturisme dan identitas budaya (Setyawan, 2006). Hutan bakau merupakan komonitas vegetasi pantai tropis, yang didominasi oleh beberapa spesies pohon bakau yang mampu tumbuh dan berkembang pada daerah pasang surut pantai berlumpur. Komonitas vegetasi ini umumnya tumbuh pada daerah intertidal dan subtidal yang cukup mendapat aliran air, dan terlindung dari gelombang besar dan arus pasang surut yang kuat. Karena itu hutan bakau banyak ditemukan di pantai-pantai teluk yang dangkal, estuaria,delta dan daerah pantai yang terlindung (Keninish, 1990)

Kerjasama UPT Tahura Ngurah Rai dengan berbagai kelompok nelayan telah terbina dengan baik. Kelompok-kelompok nelayan ini menjaga dengan baik pertumbuhan dan kebersihan lingkungannya, serta adanya dukungan penuh dari masyarakat setempat yang sudah menyadari pentingnya melestarikan hutan bakau dan salah satu kelompok yang mengelola kawasan tersebut adalah Kelompok Nelayan Segara Guna Batu Lumbang Denpasar Selatan bekerjasama Dinas Kelautan Kota Denpasar. Luas kawasan utama hutan bakau yang menjadi area pelayanan langsung kelompok nelayan adalah sekitar 288 hektar dari sekitar 800 hektar kawasan hutan bakau di sekitar sisi utara dan barat pelabuhan Benoa sampai kawasan Tuban. Secara harafiah, kawasan hutan bakau di Denpasar selatan adalah bagian kecil dari luasan hutan bakau dunia sekitar 3\% dari luas seluruh kawasan hutan dan $25 \%$ dari seluruh hutan bakau didunia (Saparinto, 2007).

Secara garis besar, bakau mempunyai beberapa keterkaitan dalam kebutuhan manusia sebagai penyedia bahan pangan, papan, dan kesehatan sehingga lingkungan dibedakan menjadi lima yaitu: Fungsi fisik, fungsi kimia, fungsi biologi, fungsi ekonomi dan fungsi lain (Dixon, 2001). Tomlinson (1986) menegaskan kawasan bakau sebagai daerah intertidal merupakan kawasan ekosistem yang spesifik yang dapat memberi manfaat multi guna bagi perairan dan juga para nelayan yang beraktifitas di tempat tersebut dalam bentuk pemanfaatan kayu mati, buah bakau, perikanan.
Dalam perjalanannya Kelompok Nelayan Segara Guna Batu Lumbang mendapat berbagai jenis pelatihan dan dukungan pembimbingan terkait antara lain Pelatihan Penyelematan Mamalia, Pelatihan Pengawasan Keamanan Kawasan Bakau, Pelatihan Penyelamatan Kawasan Utama dan Penunjang, Pelatihan Penanganan Kebakaran Kawasan Hutan Bakau, Pelatihan pemanfaatan rumpon di kawasan hutan bakau, Pengembangan lingkungan pada Dam Estuari, Pelatihan penanaman bibit bakau, Pelatihan penanganan sampah kiriman terutama plastik yang berasal dari Tukad Badung dan Tukad Mati.

Sebagai garda terdepan dalam menjaga kelestarian lingkungan kawasan hutan bakau, kelompok nelayan ini memiliki tugas yang sangat berat sebagai konsekwensi dari pemanfaatan kawasan hutan bakau bagi kelompok nelayan tersebut yakni Mencegah penebangan liar di kawasan hutan bakau, Mencegah penangkapan ikan dengan sat kimia atau listrik, Mencegah penyelundupan yang dilakukan oleh kapal-kapal gelap, Menjaga keasrian kawasan pesisir hutan bakau dengan menjaga kebersihan areal kawasan secara rutin, Bersama petugas patrol dari UPT Taman Hutan Bakau melakukan tugas pengawasan secara periodik yang dapat mengganggu keamanan dan kenyamanan kawasan hutan bakau yang berbatasan langsung dengan pelabuhan Benoa, jalan toll Ngurah Rai, Pelabuhan Udara Ngurah Rai dan lingkungan pesisir Tuban dan Nusa Dua.

\section{Pelaksanaan}

Pelaksanaan kegiatan didahului dengan observasi lapangan dan koordinasi dengan pengurus kelompok nelayan tentang langkahlangkah pelaksanaan kegiatan bersama para pengurus dan anggota kelompok nelayan. Observasi dilakukan untuk menentukan titip kawasan tempat pelaksanaan kegiatan sesuai dengan waktu pasang surut mengingat luasnya kawasan hutan bakau. Hasil observasi memutuskan untuk melaksanakan kegiatan pengambilan sampah plastik yang tersangkut di pohon bakau pada area pertemuan Tukad Mati, Tukad Badung dan Pintu keluar Dam Estuari 
Nusa Dua pada kawasan sejauh dua kilometer mulai dari Posko Nelayan.

Berdasarkan hasil observasi dilakukan percakapan mendalam untuk menentukan langkah-langkah pelaksanaan kegiatan sebagai berikut (a) waktu pelaksanaan kegiatan dilaksanakan waktu pasang surut yang cukup panjang sekitar tiga sampai empat jam (pukul sembilan sampai duabelas pagi); (b) jumlah mahasiswa yang melaksanakan kegiatan di lapangan tidak lebih dari lima belas orang dengan tujuan tidak mengganggu fauna dan flora di kawasan perairan hutan bakau; (c) setiap tim pembersih terdiri dari satu kano dengan dua orang mahasiswa yang bertindak sebagai pendayung dan pengait sampah plastik; (d) setiap tiga tim didampingi satu orang nelayan yang mengawasi dan semua tim diawasi oleh nelayan melalui boat utama; (e) waktu yang diberikan maksimal dua jam dan semua sampah sudah ditimbang dan dikumpulkan pada tempat yang telah ditentukan; (f) peserta lapangan dalam keadaan sehat, mempergunakan kelengkapan sesuai protocol kesehatan, mengikuti petunjuk etika yang diinformasikan oleh nelayan, memakai safety jacket, tidak membawa hp kecuali camera saku yang terkait dengan tali pengaman; (g) perlengkapan yang dibawa pengait manual atau electric, plastik bag, dan tas punggung.

Pelaksanaan kegiatan pada hari $\mathrm{H}$ berlangsung sekitar lima jam mulai dari persiapan dan ceramah satu setengah jam, kegiatan pengambilan sampah plastik sekitar dua setengah jam, dan evaluasi sekitar satu jam. Dari pelaksanaan tidak ada kecelakaan dan semua berjalan sesuai rencana. Dari semua sampah plastik yang dikumpulkan sampah plastik terkumpul sekitar delapan kantong plastik bag yang totalnya sekitar seratus delapan puluh lima kilogram terdiri dari berbagai jenis plastik mulai dari tas kresek terbanyak, kotak makanan, tali-tali, gabus dan busa. Semua sampah itu didapat dari pohon bakau baik yang tersangkut di dahan maupun terperangkap pada batang pohon. Sampah yang terkumpul di tamping pada box penampung utama yang kemudian diambil oleh DKP Kota Denpasar untuk dibawa ke bank sampah kota Denpasar untuk diolah lebih lanjut.
Hasil evaluasi menunjukkan bahwa para mahasiswa semakin mengerti situasi lapangan yang serius tentang bahaya sampah plastik bagi pertumbuhan pohon bakau dan berdampak kepada proses konservasi terutama dampak bagi perairan karena kawasan hutan bakau menjadi tempat yang penting bagi proses pertumbuhan anak-anak berbagai jenis ikan, destinasi para burung migrasi, burung local, biawak, ular dan jenis kera tertentu. Dengan meminimalkan dampak sampah terutama plastik maka kualitas air di perairan kawasan hutan bakau juga menjadi lebih baik dan memungkinkan semua proses konservasi menjadi lebih baik lagi. Bagi mahasiswa kegiatan lapangan ini memberi kesan mendalam karena selama pengambilan sampah ke jalur-jalur pohon bakau mereka bisa melihat langsung beberapa jenis burung, biawak, ular, dan ikan.

\section{KESIMPULAN}

Kegiatan pengabdian bersama mahasiswa di kawasan perairan hutan bakau sangat memberikan pengalaman baru bagi para mahasiswa dan sangat bermanfaat untuk mendukung kegiatan pengabdian bersama kelompok nelayan secara berkelanjutan karena kegiatan seperti pengambilan sampah plastik bisa dilakukan berkelanjutan setiap saat terutama bagi program studi yang mahasiswanya berjumlah banyak sehingga bisa dibagi kedalam kelompok kecil.

Kegiatan pengabdian di kawasan perairan hutan bakau sangat bermanfaat dalam memberikan pembelajaran edukasi tentang lingkungan secara teori dan prakteknya yang akan meningkatkan kesadaran para mahasiswa atau pelajar untuk memahami pentingnya menjaga lingkungan sebagai sebuah bentuk kampanye lingkungan terutama di destinasi pariwisata dalam mendukung sustainable tourism development.

Kegiatan pangabdian di kawasan tidak memerlukan biaya yang besar karena peralatan yang dipakai dapat dipergunakan berkali-kali serta dapat ditiipkan pada posko nelayan yang juga bisa dipakai oleh mahasiswa atau pelajar dari lembaga pendidikan lain terlebih lagi dukungan dari kelompok nelayan sangat baik 
dan memberikan semangat. Oleh karena itu kegiatan seperti ini bisa dilakukan lebih sering lagi terjadwal dalam setiap semester pembelajaran.

Implikasi pengabdian kepada masyarakat yang dilakukan di kawasan perairan taman huta bakau Denpasar dapat dijadikan sebagai kegiatan tetap dari Universitas melalui program studi yang ada dan dituangkan dalam sebuah kerjasama yang juga dapat diikuti dengan penelitian dosen sesuai dengan bidang masing-masing yang terkait dengan konservasi lingkungan. Dan yang terpenting kegiatan ini dapat memberikan jawaban langsung terhadap persoalan sampah plastik melalui kegiatan pengumpulan sampah plastik secara langsung di lokasi sehingga memberikan dampak positif pada kesehatan hutan bakau dan perairan di kawasan tersebut.

Hasil pengabdian ini telah menggambarkan sebuah eksplorasi terhadap bentuk kegiatan pengabdian dalam melihat fenomena permasalahan limbah di kawasan perairan hutan bakau dalam bentuk kegiatan yang menguntungkan dan memberikan manfaat bagi masyarakat dalam hal ini kelompok nelayan melalui sebuah kegiatan yang menerapkan prinsip-prinsip kegiatan lingkungan yang berkesinambungan melalui kegiatan nyata yang merupakan kebutuhan masyarakat di tempat tersebut walaupun masih ada keterbatasan-keterbatasan karena terbatasnya waktu dan sumber daya dalam kegiatan ini. Kegiatan pengabdian tersebut memberikan kekuatan sebagai sebuah aktifitas yang bermanfaat bagi masyarakat dan memberikan pengalaman baru bagi para mahasiswa.

Implikasi bagi dunia pendidikan memberikan ruang untuk mendukung perencanaan dan pembangunan di destinasi wisata yang mengedepankan prinsip-prinsip pembangunan pariwisata yang berkelanjutan dengan fokus kegiatan lingkungan dengan memberikan manfaat yang nyata bagi masyarakat dan meningkatnya kualitas kawasan perairan hutan bakau dalam menopang destinasi wisata secara menyeluruh.. Dan lembaga pendidikan apat melanjutkan berbagai kegiatan terpadu untuk memperkuat perencanaan dan pengembangan konservasi dalam berbagai bentuk penelitian dan kegiatan yang dapat memberikan manfaat ekonomi dan lingkungan bagi masyarakat nelayan setempat.

\section{UCAPAN TERIMA KASIH}

Kami mengucapkan terima kasih banyak kepada Pengurus dan Anggota Kelompok Nelayan Segara Guna Batu Lumbang yang sudah sangat mendukung dan memberi semangat kepada manajemen Program Sarjana Terapan D4 Manajemen Perhotelan Universitas Dhyana Pura. Semoga jalinan kerjasama yang sudah berlangsung beberapa tahun bisa ditingkatkan lagi dengan menambah agenda kegiatan pengabdian yang selama ini dilakukan dua kali per semester ditingkatkan lagi menjadi kegiatan rutin bulanan.

Kami mengucapkan terima kasih dan penghargaan kepada para dosen dan mahasiswa Prodi D4 Manajemen Perhotelan Universitas Dhyana Pura yang sudah terlibat terutama para mahasiswa yang enthuastic mengikuti kegiatan tersebut mulai dari perencanaan, observasi dan pelaksanaan lapangan. Semoga pengalaman tersebut dapat di sharing kepada para mahasiswa lain, keluarga, masyarakat.

\section{Referensi}

Bengen, D. G. 2002. Ekosistem dan sumberdaya pesisir dan laut serta pengelolaan secara terpadu dan berkelanjutan. Prosiding pelatihan pengelolaan wilayah pesisir terpadu. Bogor, 29 Oktober - 3 November 2002.

Callanan, Michelle and Sarah Thomas., 2005, "Volunteer Tourism - Deconstructing volunteer activities within a dhynamic environment" in Niche Tourism: Contemporary issues, trends and cases, edited by Marina Novelli. Oxford and Burlington: Elsevier Butterworth Heinemann

Dixon, J.A. 2001. Valation of Bakaus. Trops Coast. Area Mgt, 4(3);1 
Hawkins, D. ; Lamoureux, K. ; Clemmons, D., 2005, Voluntourism as a catalyst for developing the potential of tourism destinations, TedQual 2005 Vol.7 No.1

Hooloway, J. Christopher, Claire Humphreys and Rob Davidson, The Business of Tourism, 8'th edition, Prentice Hall, Essex, England, 2009.

Keninish, M.J. 1990. Ekologi of Estuaries. Volume II: Biological Aspects. CRC Press Inc. Boca Raton Flodida.

Kirsten Holmes and Karen Smith, Managing Volunteers in Tourism, Elsevier USA, 2009

Kristin Lamoureux, 2015, Adventure tourism in the region of Western Macedonia, International Hellenic University Repository
Saparinto.C. 2007. Pendayagunaan Ekosistem Bakau. Penerbit Dahara Prize Semarang.

Setyawan, A.W. 2006. Conservation problems of bakau ecosystem in coastal area of Rembang Regency, Central Java. Biodiversitas, 7 (2): 159- 163

Tomlinson, 1986. The Botany Of Bakau. Cambridge Universitas Press.

Wearing, Stephen. Volunteer Tourism: Experiences that make a difference. Wallingford and Cambridge (USA): Cabi Publishing, 2001.

WTTC Report: Agenda 21 For Travel \& Tourism Industry 